\title{
Analysis of the Physico-chemical Characteristics of Brewers Spent Grain (BSG)
}

\author{
Yohannes Kebede \\ College of Agricultre and Natural Resources, Debre Markos University, PO box 269, Debre Markos, Ethiopia
}

\begin{abstract}
Brewer's spent grains are byproducts produced in large quantities from the brewing industry. Characterizing agroindustrial wastes is an important step to add value and increase its viability for various applications. In this experiment, the physico-chemical characteristics of Brewers Spent Grain (Total solids, volatile solids, organic carbon, total nitrogen) were analyzed. (APHA, 1999) standard was used to analyze the characteristics. The results revealed that, BSG has a total and volatile solid content of 94.95 and $90.04 \%$, respectively. The carbon to nitrogen ratio of brewer's spent grain was 13.91. After pre-treatment the moisture content and ash content were found to be $5.05 \%$ and $10.96 \%$ respectively. It was shown that BSG exhibits higher variations according to barley variety, planting time and mashing process in the factories.
\end{abstract}

Keyword: BSG, total solid, volatile solid, Carbon to nitrogen ratio

DOI: $10.7176 / \mathrm{JNSR} / 11-18-02$

Publication date:September $30^{\text {th }} 2020$

\section{Introduction}

The brewing industry generates relatively large amounts of by-products and wastes: spent grain, spent hops and yeast being the most common. Brewery spent grain is the major by-product, corresponding to around $85 \%$ of total by-products generated in the brewing process (Aliyu \& Bala, 2011).

Spent grains are the by-products of mashing process; which is one of the initial operations in brewery in order to solubilize the malt and cereal grains to ensure adequate extraction of the wort: water with extracted matter. The filtered wort is subsequently brewed to beer, whereas the BSG is traditionally used as a relatively low value cattle feed.

BSG is a structurally extremely heterogeneous matrix comprising a mixture of barley grain husk, pericarp and fragments of endosperm. Carbohydrates comprise about half of the dry mass of BSG, the rest being mostly proteins and lignin (Forssell, et al., 2008). The protein and lignin content depend on the raw materials used and processing methods applied. Reported numbers vary between $15-27 \%$ and $12-28 \%$ of dry matter (DM), respectively.

The components of BSG consist of the barley malt grain husks, pericarp, and seed coat layers of the grains (Mussatto, et al., 2006, Lynch, et al., 2016). BSG are lignocellulosic materials that contain cellulose, non-cellulosic polysaccharides, and lignin. Also, BSG fractions are abundant in proteins, essential amino acids, fiber, and phenolic compounds (Ikram, et al., 2017). Nutrients such as lipids, fatty acids, and polyphenols are also present in BSG. The most common lipids are triglyceride and the fatty acids: linoleic, palmitic, oleic, -linoleic, and stearic acids. Other fatty acids, including myristic and vaccenic acids, are also present in lower amounts (Farcas, et al., 2015).

Lipids are also enriched in BSG and have been found to comprise 4-10\% of the DM. BSG carbohydrates are composed of arabinoxylans, cellulose, $\beta$-glucan and traces of starch. The structure of the outer layers in barley kernel is very complex and it has been suggested that it is composed of cellulose microfibrils and arabinoxylans which may form a complex with lignin (Forssell, et al., 2008).

BSG is basically a lignocellulosic material, the major constituents of which are fibre (hemicellulose and cellulose), protein and lignin. Fibre constitutes about half of the BSG composition on a dry weight basis, while proteins can constitute up to $30 \%$. This high fibre and protein content make BSG an interesting raw material for both food and non-food applications (Mendis and Simsek, 2014)

Hemicellulose, primarily consisting of arabinoxylan (AX), is the main BSG constituent and can be present at a level of up to $40 \%$ on a dry weight basis. AX is the main non-cellulose polysaccharide in cereals and grains.

The brewery industry releases huge amount of BSG every day as a byproduct of the brewery process. According to (Forssell, et al., 2008), spent grain represents approximately $20 \mathrm{~kg}$ per $100 \mathrm{~L}$ of beer produced. BSG is available at low cost throughout the year and is produced in large quantities.

However, BSG is difficult to store because of the rapid deterioration owing to microbial activity and, therefore, it is not always suitable for food applications. In addition, the environmental implications of increased methane emission owing to this hard-to-digest material are gaining attention (Cook, 2011).

Currently, most of the BSG is used as animal feed, which contribute to methane gas production, while the minority are disposed in landfills. Hence, other more economical and environmentally friendly uses for BSG are needed. 
Despite its potential as a valuable and renewable resource for industrial exploitation, it has received little attention as a marketable product yet. Its chemical composition (high nitrogen content, fibres,) makes BSG very useful for the production of high-added-value input in the industrial sector.

In order to utilize as a value-added input or utilization in the biotechnology industry it is important to characterize physicochemical characteristics of BSG.

\section{Methodology}

\subsection{Determination of the characteristics of $B S G$}

2.1.1. Total solids (TS)

Sample BSG was weighed in a crucible using electrical balance. $5 \mathrm{~g}$ of each sample was weighed and placed inside an electric hot air-oven maintained at $105^{\circ} \mathrm{C}$. The crucible is allowed to remain in the oven for 24 hours, and then taken out, cooled in a desiccator, and weighed (APHA, 1999). The weight of the sample, which was left in the oven, gives the total solids and it is represented in percentage basis.

$$
\begin{gathered}
\% \mathrm{TS}=\frac{m 2}{m 1} * 100 \\
\text { Where, } \mathrm{m}_{1}=\text { Initial weight } \\
\mathrm{m}_{2}=\text { Mass after evaporated in oven } \\
\% \mathrm{TS}=\text { percentage total solid }
\end{gathered}
$$

\subsubsection{Analytical Procedure for VS}

The volatile solids (VS) in organic wastes are measured as total solids minus the ash content, as obtained by complete combustion of the feed wastes. Volatile solid contains largely carbon, oxygen and nitrogen that burn off an already dry sample in a laboratory furnace at $500-600{ }^{\circ} \mathrm{C}$, leaving only the ash which contains largely calcium, magnesium, phosphorus, potassium and other mineral elements that do not oxidize. The VS content was determined as follows. After determining the final weight in total solids analysis, the respective cooled oven dried BSG sample was placed in a muffle furnace and ignited at $550^{\circ} \mathrm{C}$ for exactly $5 \mathrm{hrs}$.

The muffle furnace dried sample was then placed and kept in desiccator for an hour. Immediately after samples were allowed to desiccate, it was weighed in the sensitive analytical measuring balance. Then the following formula was applied to calculate the percentage of volatile solid content of the TS (APHA, 1999).

$\mathrm{VS} \%=\frac{m 2-m 3}{m 2} * 100$

$$
\begin{aligned}
& \text { Where, } \mathrm{m} 1=\text { Initial weight } \\
& \mathrm{m} 2=\text { Mass of sample after evaporated in the oven } \\
& \mathrm{m} 3=\text { Mass after ignition at } 550 \mathrm{oC}, \\
& \% \mathrm{VS}=\text { Percentage of volatile solids }
\end{aligned}
$$

Fixed solids (FS)

It is the mass of the ash remaining after ignition at $550{ }^{\circ} \mathrm{C}$.

$$
T S=V S+F S
$$

\subsubsection{Organic Carbon determination}

An estimate of the amount of carbon in a feedstock component can be calculated from the Volatile Solids (VS) content of the dried material. The percentage composition of carbon can be calculated by applying the following equation as described by (Haug, 1993).

\subsubsection{Nitrogen determination}

$$
\% \text { Carbon }=\frac{\% V S}{1.8} * 100
$$

The total nitrogen of sample BSG was determined by the Kjeldahl procedure. Digestion of the organic material was performed by the addition of concentrated sulphuric acid to $1 \mathrm{~g}$ sample of feed stocks in the digestion tube. It was heated at $370{ }^{\circ} \mathrm{C}$ by the addition of Selenium as a catalyst for the digestion process. The solution was distilled with $1.5 \mathrm{~N} \mathrm{NaOH}$ solution that can convert the ammonium salt to ammonia. The amount of ammonia present in the sample was determined by titrating it in boric acid. The boric acid captures the ammonia gas. Finally, the amount of nitrogen in a sample can be calculated from the quantified amount of ammonia ions in the receiving boric acid solution (APHA, 1999).

Finally, the carbon to nitrogen ratio of each treatment is calculated by applying simple mathematics as:

$$
\mathrm{C}: \mathrm{N}=\frac{\% \text { Carbon }}{\% \text { Nitrogen }}
$$

\section{Results and Discussion}

\subsection{Characteristics of the feed stock}

The total solid and volatile solid contents of BSG was found and summarized as follows. 
Table 3-1 Characteristics of the feedstock

\begin{tabular}{|l|l|}
\hline Parameter & Spent Grain (\%) \\
\hline TS & 94.95 \\
\hline VS & 89.04 \\
\hline MC & 5.05 \\
\hline Ash & 10.96 \\
\hline
\end{tabular}

The total solid content of brewer's spent grain is $94.95 \%$. It consists of a volatile solid and ash content of $89.04 \%$ and $10.96 \%$ respectively. This shows that a large fraction of BSG is biodegradable. This shows, BSG has high potential for utilization as biodegradable substrate for various biotechnology and industrial applications. The total solid content of BSG in this study is far more than that reported (17.6 \pm 5 ) by (Kivaisi \& Mukisa, 2000). This wide difference was observed due to pretreatment in this study has reduced its moisture content to a significant level; whereas the volatile solid content of $89.04 \%$ is in accordance with a value of $90.7 \pm 4.7 \%$. This value (89.04) is in the range of 70 to $90 \%$ for different feed stocks as described by (Steffen, et al., 1998).

\subsection{Carbon and Nitrogen content of $B S G$}

Table 3-2 Carbon and Nitrogen fraction of BSG

\begin{tabular}{|l|l|}
\hline Parameter & Brewers Spent Grain (\%) \\
\hline $\mathrm{C}$ & 53 \\
\hline $\mathrm{N}$ & 3.81 \\
\hline $\mathrm{C}: \mathrm{N}$ & 13.91 \\
\hline
\end{tabular}

Table 3.2 shows the $\mathrm{C}: \mathrm{N}$ ratio of brewers' spent grain is $13.9 \%$. The carbon content of BSG was $53 \%$ which is higher than that reported by (Khidzir, 2010) as $35.6 \pm 0.3 \%$. (Uzodinma, 2007), reported a carbon content of $47.2 \%$ which is a bit lower than the result of this study.

The total nitrogen content of BSG obtained in this study (3.81\%) is in between the values $1.025 \pm 0.05 \%$ and $4.53 \%$ as reported by (Khidzir, 2010) and (Ezekoye, 2009) respectively.

According to (Xiros \& Christakopoulos, 2009), the chemical composition of BSG varies according to barley variety, harvest time, malting and mashing conditions, and the quality and type of adjuncts added in the brewing process and hence the physicochemical characteristics of BSG varies and there is a value range for data of several BSG characteristics.

\section{Conclusion}

Increasing efforts are being directed towards the reuse of agro-industrial by-products, from both an economic and environmental viewpoint. BSG is plentiful by-product produced in breweries worldwide.

Physicochemical analysis revealed that there is higher total solid and volatile solid amount in BSG. This makes BSG ideal for various biotechnology applications and anerobic digestion.

\section{References}

Aliyu, S., \& Bala, M. (2011), "Brewer's spent grain: A review of its potentials and applications", African Journal of Biotechnology 10(3), 324-331.

American Public Health Association (APHA). (1999), "Standard method for the examination of water and waste water," American Public Health Association, Washington DC.

Cook, D. (2011), “Brewers' grains: opportunities abound,” Brewers' Guardian November/December, 60-63,

Ezekoye, V. (2009). "Studies on the Influence of Rice Husk on Biomethanation: 1. Optimal Condition for Digestion and the Domestic Use of Stored Biogas". The Pacific Journal of Science and Technology, 10(2), 889-897.

Fărca,s, A.C.; Socaci, S.A.; Dulf, F.V.; Tofană, M.; Mudura, E.; Diaconeasa, Z. (2015), "Volatile profile, fatty acids composition and total phenolics content of brewers' spent grain by-product with potential use in the development of new functional foods," J. Cereal Sci., 64, 34-42.

Forssell, P., Kontkanen, H., Schols, H., Hinz, S., Eijsink, Vincent, G., Buchert, J. (2008). "Hydrolysis of Brewers' Spent Grain by Carbohydrate Degrading Enzymes. J. Inst. Brew., 306-308.

Haug, R. (1993). "The practical handbook of compost engineering”, Lewis Publishers, Florida

Ikram, S.; Huang, L.; Zhang, H.; Wang, J.; Yin, M. (2017), "Composition and Nutrient Value Proposition of Brewers Spent Grain," J. Food Sci., 82, 2232-2242.

Khidzir, A., Noorlidah, A., \& Agamuthu, P. (2010), "Brewery Spent Grain: Chemical characteristics and utilization as an Enzyme Substrate" Malaysian J. Sci. 29(1), 41-51.

Kivaisi, A., \& Mukisa, J. (2000), "Composition and anaerobic digestion of single and combined organic fractions of municipal solid waste of Dar ES Salam”, Tanz. J. Sci. (26).

Lynch, K.M.; Ste en, E.J.; Arendt, E.K, (2016), "Brewers' spent grain: A review with an emphasis on food and health," J. Inst. Brew., 122, 553-568. 
Mendis, M., and Simsek, S. (2014), “Arabinoxylans and human health”, Food Hydrocoll. 42, 239-243.

Mussatto, S.I.; Dragone, G.; Roberto, I.C. (2006), “Brewers' spent grain: Generation, characteristics and potential applications", J. Cereal Sci., 43, 1-14.

Steffen, R., Szolar, O., \& Braun, R. (1998), "Feedstocks for Anaerobic Digestion” Viena. Retrieved February 12 , 2012, from www.adnett.org/dl feedstocks.pdf

Uzodinma, E., Ofoefule, A., Eze, J., \& Onwuka, N. (2007), "Biogas production from blends of agro-industrial wastes", Trends in applied science research 2(6), 554-558.

Xiros, C., \& Christakopoulos, P. (2009), "Enhanced ethanol production from brewer's spent grain by a Fusarium oxysporum consolidated system”, Biotechnology for Biofuels, 2(4), 1-12. 